\title{
Testing the parent-child communication program: Its effectiveness on developing children's social competences
}

\author{
${ }^{* 1}$ Agus Mulyanto; ${ }^{2}$ Alifah Indalika Mulyadi Razak \\ ${ }^{1,2}$ Department of Early Childhood Education, Universitas Islam Nusantara \\ Jl. Soekarno-Hatta No. 530, Buahbatu, Kota Bandung, West Java 40286, Indonesia \\ ${ }^{*}$ Corresponding Author. E-mail: agusmulyantouin@gmail.com
}

Submitted: 02 August 2018 | Revised: 16 April 2019 | Accepted: 07 May 2019

\begin{abstract}
Social competence has a central role in the development of early childhood. One of the central roles of children's social competence is its influence on children's academic social abilities, such as the ability to (1) receive learning information, (2) follow the school's rules, and (3) face increasingly complex academic challenges along with increasing school levels. This study aims to test the model of parent-child communication (PCC) in developing children's social competence. The exclusive communication model was tested to 250 children aged 4-6 years in West Java Province, which is divided into five research zones, West Java Zone 1 to 5. This study used an experimental design pre-test and post-test to determine the effectiveness of the parent-child communication program that was tested through observation and interview techniques consisting of 68 items of social competence. The results show that the PCC Program can effectively be applied by the collaboration of parents between fathers and mothers to optimize children's social competencies. The PCC program, which was not attended by both parents, would not be effective, for example, as happened in the West Java Zone 1, indicating the ineffectiveness of the PCC program because of the characteristics of parental activities that both work and do not have time to communicate with children. While in the other four West Java Zones PCC can be effective, because working parents want to take the time to interact and communicate actively with their children.
\end{abstract}

Keywords: parent-child communication, social competences, cbildren

Permalink/DOI: https://doi.org/10.21831/reid.v5i1.20679

\section{Introduction}

Social competence is considered to play an essential role in child development. Izard et al. (2001) explain that social competence can affect children's academic abilities. Social competence includes the ability to know yourself, know the environment, manage interaction with the environment, share ability, gain prosocial skills, manage the challenges of learning in school, recognize the various emotional expressions, and make friends. The results of another study indicate that social competence can have a significant effect on the academic social life of a child (Kail, 2012). A child who has good social competence is predicted to have good performance at school
(Papalia, Feldman, \& Martorell, 2012). The result of a survey conducted to the teachers of the Pembina State Kindergarten in West Java shows that 4-to-6-year-old children who were in kindergarten groups still need maximum stimulation in order to improve their social competence (Mulyanto, Muchtar, Hanafiah, Hoerudin, \& Razak, 2017), such as in the subcompetence of prosocial behavior, self-concept, emotional well-being, and academic-social life. In addition, Mulyanto et al. (2017) also argue that $50 \%$ of kindergarten children attending school at Pembina State Kindergartens in West Java Province have not shown maximum social competence.

It is clear that children's social competence is influenced by various community 
contexts (Kärtner, Keller, \& Chaudhary, 2010). Various efforts are made to stimulate the development of children's social competence, one of which is by giving rewards in the form of praise, star symbol, or toy that can effectively improve children's prosocial behavior, which is, one of the indicators of social competences (Fabes, Fultz, Eisenberg, May-Plumlee, \& Christopher, 1989). Besides, storytelling activities (Mincic, 2007), video games (Greitemeyer \& Osswald, 2010), and lego games (Pang, 2010) are also proven to be an alternative to improve children's social competence. This form of stimulation is inseparable from the participation of parents and teachers to direct the children in developing their social competence, as evidenced by the research conducted by Berns (1997) that presents the involvement of teachers and parents as one of the successes of school programs. The problem that then arises is if parents and teachers have established good communication, then, how the communication between parents and children are performed, so that learning information to improve children's social competence in school can also be aligned with routine activities at home.

Answering the above questions, Jhon Bowlby's attachment theory introduces Parent-Child Communication (PCC) is a form of parent and child communication (Papalia et al., 2012; Schneider, Atkinson, \& Tardif, 2001). The established communication involves an emotional bond between parent and children. It is hoped that there will be a mutual attachment contributed in establishing a high-quality relationship in accordance with the understanding of the concept of the attachment (Bus, Belsky, van Ijzendoom, \& Crnic, 1997; Schneider et al., 2001). Through the PCC program, children feel safe and comfortable to tell their parents about what they feel and what they want to convey. Besides, parents can also ask children to do or behave in a certain way so that both parties can easily negotiate and find solutions to the events at hand. The PCC has been implemented in 2006 (Niles, Reynolds, \& Nagasawa, 2006) as a form of program to convey cognitive information from parents to children, by using learning media as the intermediaries of par- ent-child communication program (Berns, 1997). Based on the previous experiences in implementing PCC, it is assumed that this program can also be effective in improving children's social competence.

\section{Method}

This study used a quantitative experimental design with the employment of before-and-after experiment design, or commonly known as pre-posttest design (Kumar, 2011). The population of this study consisted of 4-6-year-old kindergarten children who attend TK Negeri Pembina in West Java. These schools were selected to become the population because the characteristics of the environmental conditions and facilities are considered homogeneous since each TK Negeri Pembina has the same service and facility standards. The total population of the TK Pembina in the province was 50 schools, and the number of the kindergarten students was ranging from 80 to 100 . Thus, the total student population was approximately 5,000 children. Therefore, the population needs to be limited through the determination of research samples by using random sampling (Kumar, 2011), so that the total study sample consists of 250 children from five zones in West Java province.

The participants of this study were 250 children from kindergarten in West Java province with characteristics of 4 to 6 years old, living with one father and one mother, and interacting with their father and mother every day. The research subjects were then grouped into 5 zones so that each zone consisted of 50 children. Consideration of the distribution of research zones is based on the geographical conditions of data collection in the province of West Java, including: (1) Zone 1 consists of kindergartens in Bandung Raya; (2) Zone 2 consists of TK in the northern part of West Java; (3) Zone 3 consists of TK in the southern part of West Java; (4) Zone 4 consists of eastern part of West Java; (5) Zone 5 consists of the western part of West Java.

This study aims to examine the effectiveness of parent-child communication programs to improve children's social competence. The PCC program is applied on the 
questions under the following cases: (1) communication when the child goes to school; (2) communication when the child comes home from school; (3) communication between day and evening; (4) communication when children have their dinner; and (5) communication when the child is at bedtime. The fiveforms parent-child communication program is carried out by parents consisting of father and mother for ten days. The research can be said to be effective if the PCC program can improve children's social competence, which consists of 68 items measured through observation and interview. Observation applied to items that can be observed, such as the ability to play with friends, the ability to help friends, and other items. Interview measurement instruments applied to items that cannot be observed, such as the ability to distinguish sad, happy, disgusting, fearful, and other facial expressions. The technique of collecting data using observations and interviews was carried out by the class teacher of each child during the pre-test and post test process. Data analysis was carried out by agreeing to the parentchild communication program through the following hypothesis testing:

$\mathrm{H}_{0}$ : There is an influence of parent-child communication intervention on child social competency

$\mathrm{H}_{1}$ : There is no influence from parent-child communication intervention on child social competency

The data were collected using observation and interview techniques consisting of 68 items of valid child social competency indicators collected in the pre-test, which were then intervened at the treatment stage, and tested for the effectiveness at the posttest, with the following research steps: (1) Implementation of social competence pre-test for children aged 4-6 years old; (2) Implementation of parent-child communication model intervention; and (3) Post-test social competence of children aged 4-6 years. Each step is elaborated as follows.

Implementation of Social Competence PreTest for 4-to-6-Year-Old Children

This activity examines children's social competence, which consists of 68 items that have been tested for validity and reliability using expert judgment. The implementation of the pre-test of social competence employs observation and interview instruments. Children are conditioned in playing activities and daily routines at school. In playing the activities, the indicators that can be observed are, for example, indicators number 1, 2, 3, 5, 6, 8, $9,11,12,13,14,15,16,17,19,20,21,22$, and 23. Each of them measures the following ability: the ability to play with friends, resolve conflicts with friends, ask about feelings of friends, like playing with friends rather than playing alone, help friends, behave well with friends, work with friends, share things, share ideas, resolve conflicts, show concern for younger children, throw jokes, distinguish between right and wrong behaviors, show sympathy, show empathy, play with older friends, lead friends, and be led by friends (Kail, 2012).

Meanwhile, the ability indicators that can be raised through the interview process are shown through the items number $4,7,10$, $14,18,28,29,30,31$, and 35 , each of which measures the ability to tell the teacher about friends' feelings, know the signs of friends who need help, show attention to friends, give advice to persuade friends, have the initiative to create a game or activity, choose the role or task given by the teacher, express choices, tell others about something, plan an action, and know the purpose of a rule (Mulyanto et al., 2017).

Implementation of Parent-Child Communication Model Intervention

The treatment is carried out simultaneously to five zones in the province of West Java. The research team asked the principal and teachers to socialize the parent-child communication (PCC) program to the parents of students in kindergarten in West Java province. This treatment took place for ten days and was followed by the parents of students (Knafo \& Plomin, 2006) consistently in the form of activities (1) communication when the children go to school; (2) communication when children go home from school; (3) communication between day and evening; (4) communication when children have dinner; 
and (5) communication when the the children are going to sleep. The implementation of this intervention was carried out by children from families of one father and one mother and consistently divided role assignments in this intervention activity.

\section{Post-Test Social Competence of Children Aged 4-6 Years.}

This activity examines children's social competence consisting of 68 items by observing and interviewing children in play activities and daily routines at school, after being given a parent-child communication program intervention. The items of social competency indicators tested were the same as the indicator items in the pre-test activities, such as the indicator items number $24,25,26,27$, $32,33,34,42,43,45,46,50,57,58,59,60$, $61,62,63,64,65,66,68$, each of which measures the ability of being enthusiastic in school, following the rules, giving focused attention for 2 minutes, giving focused attention for 8 minutes, being brave to be left by the family members when the students are at school, running routine activities, completing two to three assignments at school, maintaining their own property, taking care of other people's goods, protecting themselves from strangers, showing the things they need, preserving the environment, controling anger, controling anxiety, controling the fear of scary things, controling the fear of darkness, controling the fear of certain situations, controling pain, controling sadness, controling the shyness to be able to have monologue, playing games, and showing confidence.

Meanwhile, the indicators of ability that can be measured through the interview process is on items number $36,37,38,39,40,41$, $44,47,48,49,51,52,53,54,55,56$, and 67 , which respectively measure the ability to distinguish men and women based on their role and physical appearance, have a tendency towards favorite objects, make positive calls to his friends, mention things they like and dislike to be able to distinguish goods by themselves and those of others, distinguish comfort and discomfort with their physical care, distinguish comfort and discomfort in their physical appearance, follow the rules for their health, recognize the happy, sad, angry, fearful, surprised, disgust, and proud facial expressions (Csoti, 2009).

\section{Findings and Discussion}

Early childhood social competence is a form of children's school readiness (Setiawati, Izzaty, \& Triyanto, 2017). Furthermore, the research in 2017 explained that children's social-emotional abilities influence almost all the development of the children. School readiness is something that can be intervened through collaboration between parents and teachers. The parent-child communication program is one of the interventions that can be applied to improve children's social competence, which has a long-term influence on school readiness.

The parent-child communication program applied in this study involves fathers and mothers who have children aged 4-6 years. The involvement of parents in implementing this program requires good cooperation. This program is carried out for ten days through five forms of communication activities. The problem is the research subject has a different condition of father and mother activities. Some children have fathers and mothers who both work from morning to night; there is also the condition of the father working from morning to night, and the mother who stays at home as a housewife. Then some children also have fathers who work and go home once a month. There are also children with conditions where their father works and returns once a month, and the mother also works from morning to night. Therefore, the implementation of the parentvertical communication program results is very diverse, spread across five zones of West Java province.

Characteristics of research subjects in West Java 1 zone (Table 1) came from kindergarten throughout Bandung Raya, most of the parents of students had activities working outside the home. The PCC program is carried out for ten days and must involve both parents. In West Java Zone 1, out of 50 parents, only 15 parents were willing to consistently join the PCC program, ranging from communication before leaving for school, communication at home from school, communica- 
tion between the afternoon and evening, communication at dinner, and communication before bedtime which were carried out completely by father and mother. The results show that the PCC program was less effective in the West Java Zone 1, which was indicated by 29 children experiencing an increase in social competence (mean positive ranks 29b = 26.81) with a total value of $777.50,19$ children experiencing a decrease in grades (mean negative ranks $19 \mathrm{a}=20.97$ ) with a total value of 398.50 , and 2 others have the same pre-test and post-test scores (ties $=2 \mathrm{c}$ ). Based on the results of the pre-test and post-test, it was concluded that $\mathrm{H}_{0}$ was accepted (Asymp.Sig $(2$-tailed $)=0.052>\alpha=0.05)$ so that there was no effect of the PCC program on the average social competence of early childhood.

The characteristics of the research subjects in West Java Zone 2 (Table 1) consisted of kindergarten in the northern region of West Java province, namely Subang, Purwakarta, and Karawang regions, amounting to 50 children. Participation in the research subject in this zone was considered very active because most of the children were accompanied by their mother at home (only the father works) so that the communication runs effectively. It is evidenced by the results of research showing that 35 people experienced an increase in social competence (mean positive ranks $35 \mathrm{~b}=26.24$ ) with a total value of 918.5. Meanwhile, 11 children experienced reduced scores (mean negative ranks $11 \mathrm{a}=14.77$ ) with a total value of 162.5, and four others had the same pre-test and post-test scores (ties $=4 \mathrm{c}$ ). Based on the results of the pre-test and posttest, it was indicated that $\mathrm{H}_{0}$ was rejected (Asymp.Sig $(2$-tailed) $=0.000<\alpha=0.05)$, so that there was an effect of the parent-child communication program on the average social competence of early childhood.

The effectiveness of the parent-child communication program is also tested in the southern West Java Zone 3 (Table 2), namely kindergarten in Garut, Cianjur, and Sukabumi regions. Even though 20 parents stated that they worked with their father and mother, they were willing to set the time and duties in joining this PCC program. Thus, 50 children were intervened effectively by their parents for ten days through the PCC program. This can be seen from the results of a study that showed 32 children experienced an increase in social competence (mean positive ranks $32 \mathrm{~b}=$ 30.09) with a total value of 963. Meanwhile, 18 children experienced a decrease in value (mean negative ranks $18 \mathrm{a}=17.33$ ) with a total value of 312 while no single sample had the same pre-test and post-test scores (ties $=0 \mathrm{c}$ ). Based on the results of the pre-test and posttest, it was indicated that $\mathrm{H}_{0}$ was rejected (Asymp.Sig $(2$-tailed $)=0.002<\alpha=0.05)$, so that there was an effect of the parent-child communication program on the average of early childhood social competence.

Table 1. Result of PCC program in West Java for Zone 1 and 2

\begin{tabular}{lcccccc}
\hline & \multicolumn{2}{c}{ West Java 1 } & \multicolumn{2}{c}{ West Java 2 } \\
\hline & N & Mean Rank & Sum of Ranks & N & Mean Rank & Sum of Ranks \\
\hline Negative ranks & $19^{\mathrm{a}}$ & 20.97 & 398.50 & $11^{\mathrm{a}}$ & 14.77 & 162.50 \\
Positive ranks & $29^{\mathrm{b}}$ & 26.81 & 777.50 & $35^{\mathrm{b}}$ & 26.24 & 918.50 \\
Ties & $2^{\mathrm{c}}$ & & & $4^{\mathrm{c}}$ & & \\
Total & 50 & & & 50 & & \\
\hline
\end{tabular}

Table 2. Result of PCC Program in West Java for Zone 3 and 4

\begin{tabular}{lcccccc}
\hline & \multicolumn{2}{c}{ West Java 3 } & \multicolumn{3}{c}{ West Java 4 } \\
& N & Mean Rank & Sum of Ranks & N & Mean Rank & Sum of Ranks \\
\hline Negative ranks & $18^{\mathrm{a}}$ & 17.33 & 312.00 & $19^{\mathrm{a}}$ & 16.92 & 321.50 \\
Positive ranks & $32^{\mathrm{b}}$ & 30.09 & 963.00 & $28^{\mathrm{b}}$ & 28.80 & 806.50 \\
Ties & $0^{\mathrm{c}}$ & & & $3^{\mathrm{c}}$ & & \\
Total & 50 & & & 50 & & \\
\hline
\end{tabular}


Improvement on children's social competence also occurs in the eastern West Java Zone 4 (Table 2), namely Ciamis and Sumedang areas, indicated by an increase in scores of 28 children (mean positive ranks $28 \mathrm{~b}=$ 28.80 ) with a total value of 806.5 . Meanwhile, 19 children experienced a decrease in value (mean negative ranks $19 \mathrm{a}=16.92$ ) with a total score of 321.5, while three samples had the same pre-test and post-test scores (ties $=3 \mathrm{c}$ ). Based on the results of the pre-test and posttest, it was indicated that $\mathrm{H}_{0}$ was rejected (Asymp.Sig (2-tailed) $=0.01<\alpha=0.05)$, so that there was an effect of the PCC program on children's social competence.

Table 3. Result of PCC program in West Java Zone 5

\begin{tabular}{lccc}
\hline & \multicolumn{2}{c}{ West Java 5 } \\
\hline & N & $\begin{array}{l}\text { Mean } \\
\text { Rank }\end{array}$ & $\begin{array}{l}\text { Sum of } \\
\text { Ranks }\end{array}$ \\
\hline Negative ranks & $19^{\mathrm{a}}$ & 18.11 & 344.00 \\
Positive ranks & $30^{\mathrm{b}}$ & 29.37 & 881.00 \\
Ties & $1^{\mathrm{c}}$ & & \\
Total & 50 & & \\
\hline
\end{tabular}

Good communication skills between parents and children are also marked in the West Java Zone 5 (Table 3), namely Bogor and Depok regions of 50 children experiencing an increase in social competence by 30 people (mean positive ranks $30 \mathrm{~b}=29.37$ ) with a total value of 881 . Meanwhile, 19 children experienced a decrease in value (mean negative ranks $19 \mathrm{a}=18.11$ ) with a total value of 344 , while one sample had the same pretest and post-test scores (ties $=1 \mathrm{c})$. Based on the results of the pre-test and post-test, it was indicated that $\mathrm{H}_{0}$ was rejected (Asymp.Sig (2tailed) $=0.008<\alpha=0.05$ ), so that there was an effect of the PCC model on the average social competence of children.

Based on the five data compiled from five areas in the province of West Java and involving 250 children and 250 pairs of parents, it is proven that the parent-child communication model consists of five forms of communication, namely: (1) communication when children go to school; (2) communication when children go home from school; (3) communication between day and evening; (4) communication when children have a din- ner; and (5) communication when the child is going to sleep. This model can be proven effective in improving early childhood social competence.

\section{Conclusion}

This study aims to examine the effectiveness of parent-child communication programs on the development of children's social competence. Children's social competence has a central position in their growth and becomes one of the main factors in children's readiness, so it requires good collaboration between parents and teachers to make it developed well. Through this parent-child communication program, parents who have diverse activities are asked to maximize their communication with children, especially in terms of improving children's social competency, which consists of 68 behavioral items.

The research findings show that the parent-child communication program can effectively improve children's social competencies consisting of 68 items. The PCC program can be implemented in the form of communication carried out by parents and children consisting of (1) communication before going to school; (2) communication when going home from school; (3) communication between the afternoon and evening; (4) communication at dinner; and (5) communication before going to bed. The five parent-child communication models are very effective in the eastern, western, southern, and also northern province of West Java as well as the condition of the research subjects with many moms and dads who spend their time at home.

\section{Acknowledgment}

The researchers deliver their gratitude to the Ministry of Research and Higher Education of the Republic of Indonesia for the research grant program so that the research results can be published.

\section{References}

Berns, R. M. (1997). Child, family, school, community: Socialization and support (4th ed.). Belmont, CA: Holt, Rinehart, and Winston, Inc. 
Bus, A. G., Belsky, J., van Ijzendoom, M. H., \& Crnic, K. (1997). Attachment and bookreading patterns: A study of mothers, fathers, and their toddlers. Early Childhood Research Quarterly, 12(1), 81-98. https://doi.org/10.1016/S08852006(97)90044-2

Csoti, M. (2009). Developing children's social, emotional, and behavioural skills. New York, NY: Continuum International Publishing.

Fabes, R. A., Fultz, J., Eisenberg, N., MayPlumlee, T., \& Christopher, F. S. (1989). Effects of rewards on children's prosocial motivation: A socialization study. Developmental Psychology, 25(4), 509-515. https://doi.org/10.1037/001 2-1649.25.4.509

Greitemeyer, T., \& Osswald, S. (2010). Effects of prosocial video games on prosocial behavior. Journal of Personality and Social Psychology, 98(2), 211-221. https://doi.org/10.1037/a0016997

Izard, C., Fine, S., Schultz, D., Mostow, A., Ackerman, B., \& Youngstrom, E. (2001). Emotion knowledge as a predictor of social behavior and academic competence in children at risk. Psychological Science, 12(1), 18-23. htt ps://doi.org/10.1111/1467-9280.00304

Kail, R. V. (2012). Children and their development (6th ed.). Upper Saddle River, NJ: Pearson Education.

Kärtner, J., Keller, H., \& Chaudhary, N. (2010). Cognitive and social influences on early prosocial behavior in two sociocultural contexts. Developmental Psychology, 46(4), 905-914. https:// doi.org/10.1037/a0019718

Knafo, A., \& Plomin, R. (2006). Parental discipline and affection and children's prosocial behavior: Genetic and environmental links. Journal of Personality and Social Psychology, 90(1), 147-164. https:/ /doi.org/10.1037/0022-3514.90.1.147
Kumar, R. (2011). Research methodology: A stepby-step guide for beginners. London: SAGE Publication.

Mincic, M. S. (2007). Dialogic reading with emotion-laden storybooks: Intervention methods to enhance children's emergent literacy and social-emotional skills. Doctoral Dissertation. Department of Psychology, George Mason University.

Mulyanto, A., Muchtar, H. S., Hanafiah, Hoerudin, C. W., \& Razak, A. I. M. (2017). Children's social competences: An early detection. International Journal of Management and Applied Science, 3(12), 70-73.

Niles, M. D., Reynolds, A. J., \& Nagasawa, M. K. (2006). Does early childhood intervention affect the social and emotional development of participants? Early Childhood Research and Practice, 8(1).

Pang, Y. (2010). Lego games help young children with autism develop social skills. International Journal of Education, 2(2), 1-9. https://doi.org/10.5296/ ije.v2i2.538

Papalia, D. E., Feldman, R. D., \& Martorell, G. (2012). Experience buman development (12th ed.). New York, NY: McGrawHill.

Schneider, B. H., Atkinson, L., \& Tardif, C. (2001). Child-parent attachment and children's peer relations: A quantitative review. Developmental Psychology, 37(1), 86-100.

Setiawati, F. A., Izzaty, R. E., \& Triyanto, A. (2017). Exploring the construct of school readiness based on child development for kindergarten children. REiD (Research and Evaluation in Education), 3(1), 42-49. https://doi.org/ 10.21831/reid.v3i1.13663 